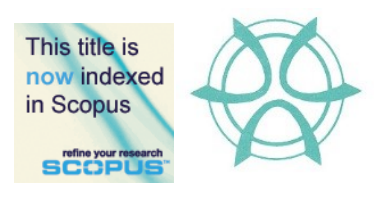

PLANNING MALAYSIA:

Journal of the Malaysian Institute of Planners

VOLUME 17 ISSUE 2 (2019), Page 302 - 311

\title{
PERSONAL EMPOWERMENT AS DETERMINANTS OF ORGANISATIONAL OPPORTUNITY
}

\author{
Aisyah Abu Bakar', Mariana Mohamed Osman² \& Muhammad Faris Abdullah ${ }^{3}$ \\ ${ }^{1,2,3}$ Kulliyyah of Architecture and Environmental Design \\ INTERNATIONAL ISLAMIC UNIVERSITY MALAYSIA
}

\begin{abstract}
Architects can influence workplace behaviours and manoeuvre workers' emotions through aligning design strategies with human moods. Design sustains organisational well-being through strengthening space occupants' empowerment, leading to better work performances. Issue: Existing research has limited empirical evidence on the impact of personal empowerment (PE) on organisational opportunity (OO). Purpose: This paper aims to verify the statistical predictability of $\mathrm{OO}$ based on PE. Approach: Multiple Correlation and Multiple Linear Regression were carried out to assess linear associations and parameters of linear equations to predict $\mathrm{OO}$ components based on PE items. Findings: $\mathrm{OO}$ components were predictable by the majority of the PE items and 'monitoring behaviours to suit with situation' was the strongest predictor of OO.
\end{abstract}

Keywords: organisational opportunity, personal empowerment 
PLANNING MALAYSIA

\section{INTRODUCTION}

Human interdependence with other humans ( $\mathrm{HIH})$ plays a big part in architectural psychology as designers now gain a new set of criteria in improving emotional aspects of spatial designs. HIH is one of the potent causes of subjective sustainable well-being (SSWB). Personal empowerment (PE) and organisational opportunity $(\mathrm{OO})$ are dimensions of $\mathrm{HIH}$. Space qualities have a tremendous impact on occupants' way of thinking, patterns of actions and, thus promote PE, leading to improved concentration, willingness to act, and ultimately, OO. Over time, extensive literature have discussed the positive effect of PE on OO. This paper assesses the statistical predictability of OO based on PE.

\section{LITERATURE REVIEW}

Case studies based on articles from selected Asian Journals from the year 2011 onwards highlight conditional factors and potential determinants of OO. Table 1 summarises these findings.

Table 1 Conditional factors and potential determinants for organisational opportunity

\begin{tabular}{|c|c|c|}
\hline Conditional Factors (Keywords) & Potential Determinants & References \\
\hline $\begin{array}{l}\text { Job security (stability and continuance of one's job), } \\
\text { organisational commitment (sense of oneness with } \\
\text { organisation), social comfort (feeling of trust with social } \\
\text { environment) and quality of work (quality of experience of } \\
\text { employees-organisation relationship). }\end{array}$ & $\begin{array}{l}\text { Co-workers involvement and } \\
\text { belongingness (willing to } \\
\text { contribute, participate, share, } \\
\text { volunteer), and sense of } \\
\text { responsibility }\end{array}$ & $\begin{array}{c}\text { Sarina \& } \\
\text { Mohamad } \\
\text { Adli (2012) }\end{array}$ \\
\hline $\begin{array}{l}\text { Financial well-being (ability to meet current and ongoing } \\
\text { financial obligation, and moderation in spending } \\
\text { (restraining self from excessive expenditure) }\end{array}$ & $\begin{array}{l}\text { Productivity (effectiveness), } \\
\text { and self-control (ability to } \\
\text { control oneself or desires) }\end{array}$ & $\begin{array}{l}\text { Mokhtar, } \\
\text { Husniyah, } \\
\text { Sabri, \& Abu } \\
\text { Talib. (2015) }\end{array}$ \\
\hline $\begin{array}{l}\text { Time-based constraint (the time demands of one role are } \\
\text { incompatible with those of another), strain-based constraint } \\
\text { (strain experienced in one role interferes with participation } \\
\text { in another role), and behaviour-based constraint (behaviour } \\
\text { pattern appropriate to one domain are inappropriate in } \\
\text { another). }\end{array}$ & $\begin{array}{l}\text { ence (ability } \\
\text { eact to owns } \\
\text { ons), self- } \\
\text { control } \\
1 \text { support } \\
\text { ne is cared }\end{array}$ & $\begin{array}{l}\text { Panatik, } \\
\text { Zainal Badri, } \\
\text { Rajab, Abdul } \\
\text { Rahman, \& } \\
\text { Mad Shaha } \\
\quad \text { (2011) }\end{array}$ \\
\hline $\begin{array}{l}\text { Work-family conflict (incompatible demands between } \\
\text { career and family roles), and personal adjustment } \\
\text { (balancing conflicting needs or certain requirements against } \\
\text { the surrounding obstacles) }\end{array}$ & $\begin{array}{l}\text { gh } \\
\text { lence in self- } \\
\text { ng from } \\
\text { vith others) }\end{array}$ & $\begin{array}{r}\text { Ras } \\
\text { Nor } \\
\text { Oma } \\
\text { Ismail }\end{array}$ \\
\hline $\begin{array}{l}\text { Work ethics (principles that hard work is virtuous and } \\
\text { believing in moral benefits of work), and passiveness in } \\
\text { taking charge (reluctant to do more than what were } \\
\text { minimally required to do). }\end{array}$ & $\begin{array}{l}\text { litment } \\
\text { rity, } \\
\text { pation, }\end{array}$ & Salin \\
\hline $\begin{array}{l}\text { Goal orientation (the ability to take charge and focus on } \\
\text { demanding tasks), bravery (courageous character), } \\
\text { achievement motivation (the need to success or attaining } \\
\text { excellence), and job performance }\end{array}$ & $\begin{array}{l}\text { e (influence over } \\
\text { ptimistic), } \\
\text { enness (frankness), } \\
\text { ness) }\end{array}$ & $\begin{array}{l}\text { Halim, Zainal, } \\
\text { Omar, Hafidz, } \\
\text { \& Othman } \\
\quad(2013)\end{array}$ \\
\hline $\begin{array}{l}\text { Job insecurity (behavioural withdrawal, perceived } \\
\text { powerlessness to maintain a desired continuity experienced, } \\
\text { and concern the possibility of being retrenched in the future) }\end{array}$ & $\begin{array}{l}\text { Optimism (hopefulness and } \\
\text { confidence for the future), and } \\
\text { confidence in hierarchy and } \\
\text { ranks of the organisation }\end{array}$ & $\begin{array}{c}\text { Ho, } \\
\text { Sambasivan, } \\
\text { \& Liew } \\
(2013) \\
\end{array}$ \\
\hline $\begin{array}{l}\text { Safety culture (an outcome of values, } \\
\text { behaviours concerning safety in the wo } \\
\text { training, resource allocation and manageme }\end{array}$ & $\begin{array}{l}\text { Commitment (dedication), and } \\
\text { leadership (guiding and } \\
\text { inspiring others) }\end{array}$ & \\
\hline
\end{tabular}


Aisyah Abu Bakar, Mariana Mohamed Osman \& Muhammad Faris Abdullah

Personal Empowerment as Determinants of Organisational Opportunity

\begin{tabular}{|c|c|c|}
\hline & & $\begin{array}{c}\text { Janipha } \\
(2012)\end{array}$ \\
\hline $\begin{array}{l}\text { Sense of empowerment given to employees in relation to } \\
\text { freedom to perform, and positive emotions translated in job } \\
\text { satisfaction. }\end{array}$ & $\begin{array}{l}\text { Competence (capability and } \\
\text { efficiency) and task } \\
\text { meaningfulness }\end{array}$ & $\begin{array}{c}\text { Aziz \& } \\
\text { Ennew (2013) }\end{array}$ \\
\hline $\begin{array}{l}\text { Social-oriented achievement (an inclination to achieve a } \\
\text { standard of excellence set by significant others (e.g. } \\
\text { teachers, parents) that is pursued and evaluated according to } \\
\text { the ways and the standards determined by others) }\end{array}$ & $\begin{array}{l}\text { Security (the state of feeling } \\
\text { safe) and conformity } \\
\text { (behaving in accordance to } \\
\text { accepted conventions or } \\
\text { standards set by society) }\end{array}$ & $\begin{array}{l}\text { Liem, Martin, } \\
\text { Porter, \& } \\
\text { Colmar 2012) }\end{array}$ \\
\hline
\end{tabular}

The findings from the case studies generate three significant components of OO: (i) Fluency and Versatility (OOa), (ii) Encouraging Interaction (OOb) and (iii) Collaborative Engagement (OOc).

Table 2 Components and determinants of organisational opportunity

\begin{tabular}{|c|c|c|c|}
\hline Definition of OO & Components & Indicators & Code \\
\hline \multirow{10}{*}{$\begin{array}{l}\text { Optimism and } \\
\text { openness expressed } \\
\text { in exchange ideas } \\
\text { and encouraging } \\
\text { interactions that } \\
\text { insinuate hope and } \\
\text { positive prospect } \\
\text { for the future in the } \\
\text { working } \\
\text { environment }\end{array}$} & Fluency and & sense of clarity and understand of tasks and roles at work & \multirow{4}{*}{$\mathrm{OOa}$} \\
\hline & Versatility & flexible in handling different work roles and diverse tasks & \\
\hline & \multirow{4}{*}{$\begin{array}{l}\text { Encouraging } \\
\text { Interaction }\end{array}$} & sharing the same stance with my co-workers & \\
\hline & & motivating and assisting co-workers at their work & \\
\hline & & cherishing co-workers' accomplishments & \multirow{3}{*}{$\mathrm{OOb}$} \\
\hline & & valuing ideas and suggestions from co-workers & \\
\hline & \multirow{4}{*}{$\begin{array}{c}\text { Collaborative } \\
\text { Engagement }\end{array}$} & being engaged in decision-making process & \\
\hline & & delivering ideas and suggestion constructively & \multirow{3}{*}{ OOc } \\
\hline & & sharing skills and knowledge eagerly with co-workers & \\
\hline & & optimistic with the hierarchy at the organisation & \\
\hline
\end{tabular}

Personal Empowerment (PE) manifests in the opportunity to exercise control, voice and choice with regards to social surroundings. Qualities adhere to PE include (i) self-motivation with regards to goal orientation, autonomy and self-regulation (Fatimah, Lukman, Khairudin, Wan Shahrazad, \& Halim, 2011; Chin, Khoo, \& Low, 2012; Kok, 2016), (ii) social acceptance and coherence with others (Fatimah et al., 2011; Nesbit, Jepsen, Demirian, \& Ho, 2012; Kadir, Omar, Desa, \& Yusooff, 2013; Zamani, Khairudin, Sulaiman, Halim, \& Nasir, 2013), and (iii) composure, stability and resilience (Sulaiman, Kadir, Halim, Omar, Latiff, \& Sulaiman, 2013; Sipon, Nasrah, Nazli, Abdullah, \& Othman, 2014).

Table 3 Determinants of personal empowerment

\begin{tabular}{|c|c|c|}
\hline Definition of PE & Indicators & Code \\
\hline \multirow{10}{*}{$\begin{array}{l}\text { Self-esteem in taking control over } \\
\text { life along with sense of composure } \\
\text { to progress in the social } \\
\text { environment }\end{array}$} & setting goals and striving to meet goals & PE1 \\
\hline & striving and working hard even for easy goals & PE2 \\
\hline & monitoring behaviours to suit with situations & PE3 \\
\hline & knowing when somebody is offended & PE4 \\
\hline & ensuring others are comfortable when making deals & PE5 \\
\hline & able to be friendly with distasteful persons when necessary & PE6 \\
\hline & able to work out solutions during stress and difficulties & PE7 \\
\hline & tackling problems efficiently in unexpected conditions & PE8 \\
\hline & feeling energetic for daily routines and activities & PE9 \\
\hline & having hardly distracted and focus mind & PE10 \\
\hline
\end{tabular}


PLANNING MALAYSIA

Journal of the Malaysia Institute of Planners (2019)

Based on theoretical underpinnings, the research hypothesize that $\mathrm{OO}$ components are predictable by PE. The following sections provide empirical evidence the predictability of $\mathrm{OOa}, \mathrm{OOb}$ and $\mathrm{OOc}$ based on PE items.

\section{METHOD}

A sample of 4,315 was gathered after the data screening process. The Malaysian respondents were given an 11-point Likert scale to respond to questionnaire items which include the components of $\mathrm{OO}$ and the ten PE items. Pearson correlation analyses were conducted to observe if there were linear associations between the $\mathrm{OO}$ components and PE items. Ensuing correlation analyses, multiple linear regression analyses were conducted to estimate parameters of the linear equations used to predict values of $\mathrm{OOa}, \mathrm{OOb}$ and $\mathrm{OOc}$ from $\mathrm{PE}$ items.

\section{RESULTS AND DISCUSSION}

At $95 \%$ confidence level, there were statistically significant positive correlations between (i) OOa and each of PE items, (ii) OOb and each of PE items, and (iii) OOc and each of PE items. The null hypotheses claiming there are no statistically significant correlations between (i) $\mathrm{OOa}$ and respective $\mathrm{PE}$ items, (ii) $\mathrm{OOb}$ and respective PE items, and (iii) OOc and respective PE items were all rejected.

Table 4 Multiple Correlations between PE items and $\mathrm{OOa}, \mathrm{OOb}$ and $\mathrm{OOc}$

\begin{tabular}{|c|c|c|c|c|c|c|c|c|c|c|c|}
\hline \multicolumn{12}{|c|}{$\mathrm{H}_{0}$ There is no statistically significant correlation between $\mathrm{OOa}$ and respective $\mathrm{PE}$ items } \\
\hline \multirow{2}{*}{\multicolumn{12}{|c|}{$\begin{array}{l}\mathrm{H}_{0} \text { There is no statistically significant correlation between } \mathrm{OOb} \text { and respective PE items } \\
\mathrm{H}_{0} \text { There is no statistically significant correlation between } \mathrm{OOc} \text { and respective PE items }\end{array}$}} \\
\hline & & & & & & & & & & & \\
\hline \multicolumn{12}{|c|}{ Correlation Strength Threshold (Dancey \& Reidy, 2004) } \\
\hline 0 & .1 & .2 &. & & 4 & 5 & .6 & .7 & .8 & .9 & 1 \\
\hline zero & \multicolumn{3}{|c|}{ weak } & \multicolumn{4}{|c|}{ moderate } & \multicolumn{3}{|c|}{ strong } & perfect \\
\hline DV & Stats & PE1 & PE2 & PE3 & PE4 & PE5 & PE6 & PE7 & PE8 & PE9 & PE10 \\
\hline \multirow{3}{*}{$\mathrm{OOa}$} & $\mathrm{r}$ & $.522 * *$ & $.511 * *$ & $.505^{* *}$ & $.430 * *$ & $.463 * *$ & $.370^{* *}$ & $.446^{* *}$ & $.422 * *$ & $.465 * *$ & $.419 * *$ \\
\hline & $p$ & .000 & .000 & .000 & .000 & .000 & .000 & .000 & .000 & .000 & .000 \\
\hline & $\mathrm{N}$ & 4315 & 4315 & 4315 & 4315 & 4315 & 4315 & 4315 & 4315 & 4315 & 4315 \\
\hline \multirow{3}{*}{$\mathrm{OOb}$} & $\mathrm{r}$ & $.469 * *$ & $.503 * *$ & $.497 * *$ & $.465^{* *}$ & $493 * *$ & $437 * *$ & $463 * *$ & $.454 * *$ & $468 * *$ & $.419 * *$ \\
\hline & $p$ & .000 & .000 & .000 & .000 & .000 & .000 & .000 & .000 & .000 & .000 \\
\hline & $\mathrm{N}$ & 4315 & 4315 & 4315 & 4315 & 4315 & 4315 & 4315 & 4315 & 4315 & 4315 \\
\hline \multirow{3}{*}{ OOc } & $\mathrm{r}$ & $.513 * *$ & $.533 * *$ & $.524 * *$ & $.491 * *$ & $.535^{* *}$ & $.463 * *$ & $.486^{* *}$ & $.479 * *$ & $.494 * *$ & $.449 * *$ \\
\hline & $p$ & .000 & .000 & .000 & .000 & .000 & .000 & .000 & .000 & .000 & .000 \\
\hline & $\mathrm{N}$ & 4315 & 4315 & 4315 & 4315 & 4315 & 4315 & 4315 & 4315 & 4315 & 4315 \\
\hline
\end{tabular}

Statistical Interpretation of Multiple Correlation Analyses

At $95 \%$ confidence level, there were statistically significant and moderate correlations between $\mathrm{OOa}$ Oa and (i) PE1 ( $\mathrm{r}=.522, \mathrm{p}=.000)$; (ii) PE2 $(\mathrm{r}=.511, \mathrm{p}=.000)$; (iii) PE3 $(\mathrm{r}=.505, \mathrm{p}=.000)$; (iv) PE4 ( $\mathrm{r}$ $=.430, \mathrm{p}=.000) ;(\mathrm{v})$ PE5 $(\mathrm{r}=.463, \mathrm{p}=.000) ;(\mathrm{vi})$ PE6 $(\mathrm{r}=.370, \mathrm{p}=.000) ;(\mathrm{vii})$ PE7 $(\mathrm{r}=.446, \mathrm{p}=.000)$; (viii) PE8 ( $r=.422, \mathrm{p}=.000)$; (ix) PE9 $(\mathrm{r}=.465, \mathrm{p}=.000)$; ( $\mathrm{x}$ ) PE10 $(\mathrm{r}=.419, \mathrm{p}=.000)$.

At $95 \%$ confidence level, there were statistically significant and moderate correlations between $\mathrm{OOb}$ and (i) PE1 ( $\mathrm{r}=.469, \mathrm{p}=.000)$; (ii) PE2 ( $\mathrm{r}=.503, \mathrm{p}=.000)$; (iii) PE3 ( $\mathrm{r}=.497, \mathrm{p}=.000)$; (iv) PE4 ( $\mathrm{r}$ $=.465, \mathrm{p}=.000)$; (v) PE5 ( $\mathrm{r}=.493, \mathrm{p}=.000)$; (vi) PE6 ( $\mathrm{r}=.437, \mathrm{p}=.000)$; (vii) PE7 ( $\mathrm{r}=.463, \mathrm{p}=$ $.000)$; (viii) PE8 ( $\mathrm{r}=.454, \mathrm{p}=.000)$; (ix) PE9 $(\mathrm{r}=.468, \mathrm{p}=.000)$; (x) PE10 $(\mathrm{r}=.419, \mathrm{p}=.000)$. 
Aisyah Abu Bakar, Mariana Mohamed Osman \& Muhammad Faris Abdullah

Personal Empowerment as Determinants of Organisational Opportunity

At 95\% confidence level, there were statistically significant and moderate correlations between OOc
and (i) PE1 $(\mathrm{r}=.513, \mathrm{p}=.000) ;(\mathrm{ii})$ PE2 $(\mathrm{r}=533, \mathrm{p}=.000) ;($ iii) PE3 $(\mathrm{r}=.524, \mathrm{p}=.000) ;($ iv) PE4 ( $\mathrm{r}$
OO.491, $\mathrm{p}=.000) ;(\mathrm{v})$ PE5 $(\mathrm{r}=.535, \mathrm{p}=.000) ;(\mathrm{vi})$ PE6 $(\mathrm{r}=.463, \mathrm{p}=.000) ;(\mathrm{vii})$ PE7 $(\mathrm{r}=.486, \mathrm{p}=$
$.000) ;($ viii) PE8 $(\mathrm{r}=.479, \mathrm{p}=.000) ;(\mathrm{ix})$ PE9 $(\mathrm{r}=.494, \mathrm{p}=.000) ;(\mathrm{x})$ PE10 $(\mathrm{r}=.449, \mathrm{p}=.000)$.

Three (3) multiple regression analyses were carried out to predict the values of each of dependent variables (i) $\mathrm{OOa}$, (ii) $\mathrm{OOb}$ and (iii) $\mathrm{OOc}$ given the set of PE explanatory variables (PE1, PE2, PE3, PE4, PE5, PE6, PE7, PE8, PE9, and PE10).

Table 5 Multiple Linear Regression - PE predicting OOa

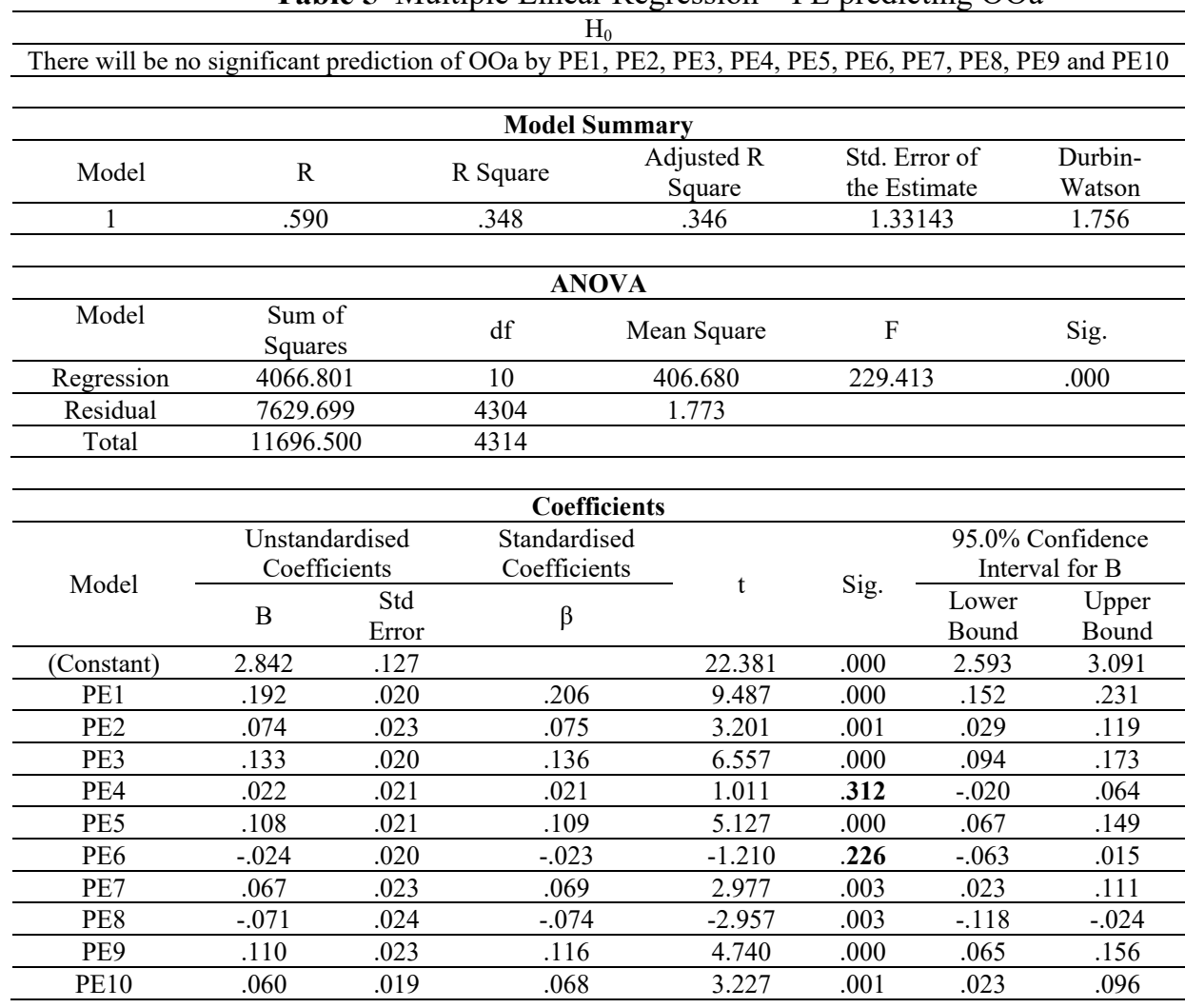

A multiple regression was generated to predict OOa based on PE items. $R$ value of .590 indicated an acceptable level of prediction ( $R>0.5)$. The DurbinWatson statistic was 1.756 which is between 1.5 and 2.5 and therefore the data was not autocorrelated. A significant regression equation was found, $F(10,4304)$ $=229.413, \mathrm{p}=.000$, with an $\mathrm{R}^{2}$ of .348 ; indicating that the proportion of variance in OOa that can be explained by PE items was $34.8 \%$.

At $95 \%$ confidence level, PE1 $(\mathrm{B}=.192, \mathrm{t}=9.487, \mathrm{p}=.000), \mathrm{PE} 2(\mathrm{~B}=$ $.074, t=3.201, \mathrm{p}=.001)$, PE3 $(\mathrm{B}=.133, \mathrm{t}=6.557, \mathrm{p}=.000)$, PE5 $(\mathrm{B}=.108, \mathrm{t}=$ 
5.127, $\mathrm{p}=.000)$, PE7 $(\mathrm{B}=.067, \mathrm{t}=2.977, \mathrm{p}=.000)$, PE8 $(\mathrm{B}=-.071, \mathrm{t}=-2.957$, $\mathrm{p}=.003)$, PE9 $(\mathrm{B}=.110, \mathrm{t}=4.740, \mathrm{p}=.000)$ and PE10 $(\mathrm{B}=.060, \mathrm{t}=3.227, \mathrm{p}$ $=.001$ ) were significant predictors of OOa. On the contrary, it was found that PE4 $(\mathrm{B}=.022, \mathrm{t}=1.011, \mathrm{p}=.312)$ and PE6 $(\mathrm{B}=-.024, \mathrm{t}=-1.210, \mathrm{p}=.226)$ were not significant predictors of $\mathrm{OOa}$.

Personal Empowerment (PE) items account for 34.8\% of Fluency and Versatility (OOa). Eight (8) of PE items were significant predictors of OOa.

Table 6 Multiple Linear Regression - PE predicting OOb

\begin{tabular}{|c|c|c|c|c|c|c|c|}
\hline \multicolumn{8}{|c|}{$\mathrm{H}_{0}$} \\
\hline There will be 1 & ignifica & prediction $\mathrm{c}$ & f OOb by & PE2, PE3, PE4, & 5, PE6, & 7, PE8, F & 9 and PE10 \\
\hline \multicolumn{8}{|c|}{ Model Summary } \\
\hline Model & \multicolumn{2}{|c|}{$\mathrm{R}$} & R Square & $\begin{array}{c}\text { Adjusted R } \\
\text { Square }\end{array}$ & \multicolumn{2}{|c|}{$\begin{array}{l}\text { Std. Error of } \\
\text { the Estimate }\end{array}$} & $\begin{array}{l}\text { Durbin- } \\
\text { Watson }\end{array}$ \\
\hline 1 & \multicolumn{2}{|c|}{.586} & .343 & .342 & \multicolumn{2}{|c|}{1.18229} & 1.760 \\
\hline \multicolumn{8}{|c|}{ ANOVA } \\
\hline Model & \multicolumn{2}{|c|}{$\begin{array}{l}\text { Sum of } \\
\text { Squares }\end{array}$} & df & Mean Square & \multicolumn{2}{|c|}{$\mathrm{F}$} & Sig. \\
\hline Regression & \multicolumn{2}{|c|}{3145.099} & 10 & 314.510 & \multicolumn{2}{|c|}{225.001} & .000 \\
\hline Residual & \multicolumn{2}{|c|}{6016.203} & 4304 & 1.398 & & & \\
\hline Total & \multicolumn{2}{|c|}{9161.302} & 4314 & & & & \\
\hline \multicolumn{8}{|c|}{ Coefficients } \\
\hline \multirow{2}{*}{ Model } & \multicolumn{2}{|c|}{$\begin{array}{c}\text { Unstandardised } \\
\text { Coefficients }\end{array}$} & $\begin{array}{l}\text { Stand } \\
\text { Coef }\end{array}$ & \multirow{2}{*}{$\mathrm{t}$} & \multirow{2}{*}{ Sig. } & \multicolumn{2}{|c|}{$\begin{array}{c}95.0 \% \text { Confidence } \\
\text { Interval for B }\end{array}$} \\
\hline & B & Std Error & & & & $\begin{array}{l}\text { Lower } \\
\text { Bound }\end{array}$ & $\begin{array}{l}\text { Upper } \\
\text { Bound } \\
\end{array}$ \\
\hline (Constant) & 3.075 & .113 & & 27.277 & .000 & 2.854 & 3.296 \\
\hline PE1 & .040 & .018 & & 2.253 & .024 & .005 & .076 \\
\hline PE2 & .115 & .021 & & 5.622 & .000 & .075 & .155 \\
\hline PE3 & .104 & .018 & & 5.742 & .000 & .068 & .139 \\
\hline PE4 & .039 & .019 & & 2.033 & .042 & .001 & .076 \\
\hline PE5 & .109 & .019 & & 5.832 & .000 & .072 & .146 \\
\hline PE6 & .066 & .018 & & 3.783 & .000 & .032 & .101 \\
\hline PE7 & .033 & .020 & & 1.669 & .095 & -.006 & .073 \\
\hline PE8 & .009 & .021 & & .411 & .681 & -.033 & .051 \\
\hline PE9 & .076 & .021 & & 3.697 & .000 & .036 & .117 \\
\hline PE10 & .031 & .016 & & 1.868 & .062 & -.002 & .063 \\
\hline
\end{tabular}

A multiple regression was generated to predict $\mathrm{OOb}$ based on PE items. $R$ value of .586 indicated an acceptable level of prediction ( $R>0.5)$. The DurbinWatson statistic was 1.760 which is between 1.5 and 2.5 and therefore the data was not autocorrelated. A significant regression equation was found, $F(10,4304)$ $=225.001, \mathrm{p}=.000$, with an $\mathrm{R}^{2}$ of .343 ; indicating that the proportion of variance in $\mathrm{OOb}$ that can be explained by $\mathrm{PE}$ items was $34.3 \%$.

At $95 \%$ confidence level, PE1 $(\mathrm{B}=.040, \mathrm{t}=2.253, \mathrm{p}=.024), \mathrm{PE} 2(\mathrm{~B}=$ $.115, \mathrm{t}=5.622, \mathrm{p}=.000)$, PE3 $(\mathrm{B}=.104, \mathrm{t}=5.742, \mathrm{p}=.000)$, PE4 $(\mathrm{B}=.039, \mathrm{t}=$ $2.033, \mathrm{p}=.042)$, PE5 $(\mathrm{B}=.109, \mathrm{t}=5.832, \mathrm{p}=.000)$, PE6 $(\mathrm{B}=.066, \mathrm{t}=3.783, \mathrm{p}$ 
Aisyah Abu Bakar, Mariana Mohamed Osman \& Muhammad Faris Abdullah

Personal Empowerment as Determinants of Organisational Opportunity

$=.000)$ and PE9 $(\mathrm{B}=.076, \mathrm{t}=3.697, \mathrm{p}=.000)$ were significant predictors of $\mathrm{OOb}$ On the contrary, it was found that PE7 $(\mathrm{B}=.033, \mathrm{t}=1.669, \mathrm{p}=.095)$, PE8 $(\mathrm{B}=$ $.009, \mathrm{t}=.411, \mathrm{p}=.681)$ and PE10 $(\mathrm{B}=.031, \mathrm{t}=1.868, \mathrm{p}=.062)$ were not significant predictors of $\mathrm{OOb}$.

Personal Empowerment (PE) items account for 34.3\% of Encouraging Interaction $(\mathrm{OOb})$. Seven (7) of $\mathrm{PE}$ items were significant predictors of OOa.

Table 7 Multiple Linear Regression - PE predicting OOc

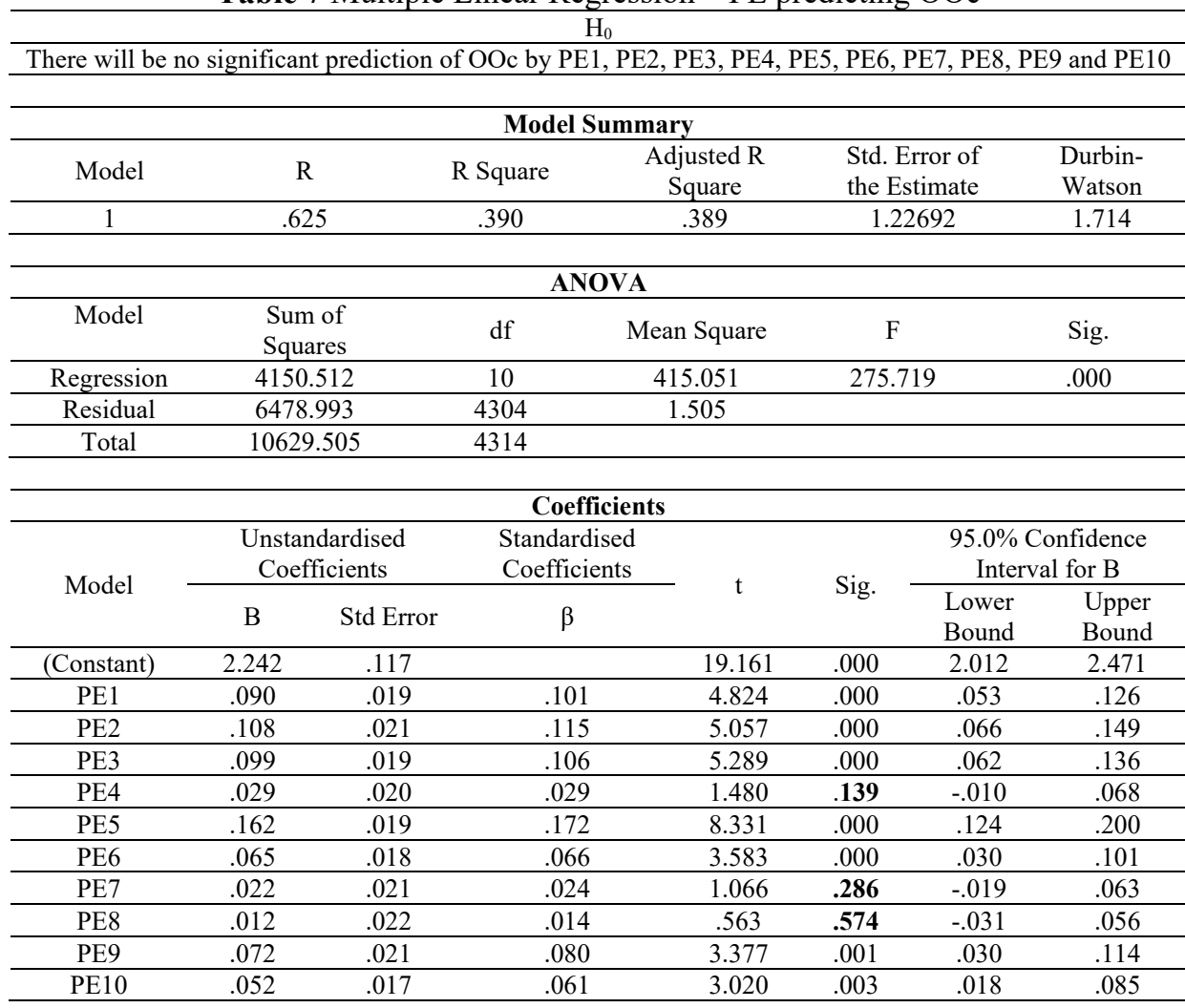

A multiple regression was generated to predict OOa based on PE items. $R$ value of .625 indicated an acceptable level of prediction $(R>0.5)$. The DurbinWatson statistic was 1.714 which is between 1.5 and 2.5 and therefore the data was not autocorrelated. A significant regression equation was found, F $(10,4304)$ $=275.719, \mathrm{p}=.000$, with an $\mathrm{R}^{2}$ of .390 ; indicating that the proportion of variance in OOc that can be explained by PE items was 39\%.

At $95 \%$ confidence level, PE1 $(\mathrm{B}=.090, \mathrm{t}=4.824, \mathrm{p}=.000)$, PE2 (B $=.108, \mathrm{t}=5.057, \mathrm{p}=.000)$, PE3 $(\mathrm{B}=.099, \mathrm{t}=5.289, \mathrm{p}=.000)$, PE5 $(\mathrm{B}=.162, \mathrm{t}=$ $8.331, \mathrm{p}=.000)$, PE6 $(\mathrm{B}=.065, \mathrm{t}=3.583, \mathrm{p}=.000)$, PE9 $(\mathrm{B}=.072, \mathrm{t}=3.377, \mathrm{p}$ $=.001)$ and PE10 $(\mathrm{B}=.052, \mathrm{t}=3.020, \mathrm{p}=.003)$ were significant predictors of 
OOc. On the contrary, it was found that PE4 $(\mathrm{B}=.029, \mathrm{t}=1.480, \mathrm{p}=.139$.$) , PE7$ $(\mathrm{B}=.022, \mathrm{t}=1.066, \mathrm{p}=.286)$ and $\mathrm{PE} 8(\mathrm{~B}=.012, \mathrm{t}=.563, \mathrm{p}=.574$.) were not significant predictors of OOc.

Personal Empowerment (PE) items account for $34.8 \%$ of Collaborative Engagement (OOc). Sevent (7) of PE items were significant predictors of OOc.

Table 8 Summary of findings

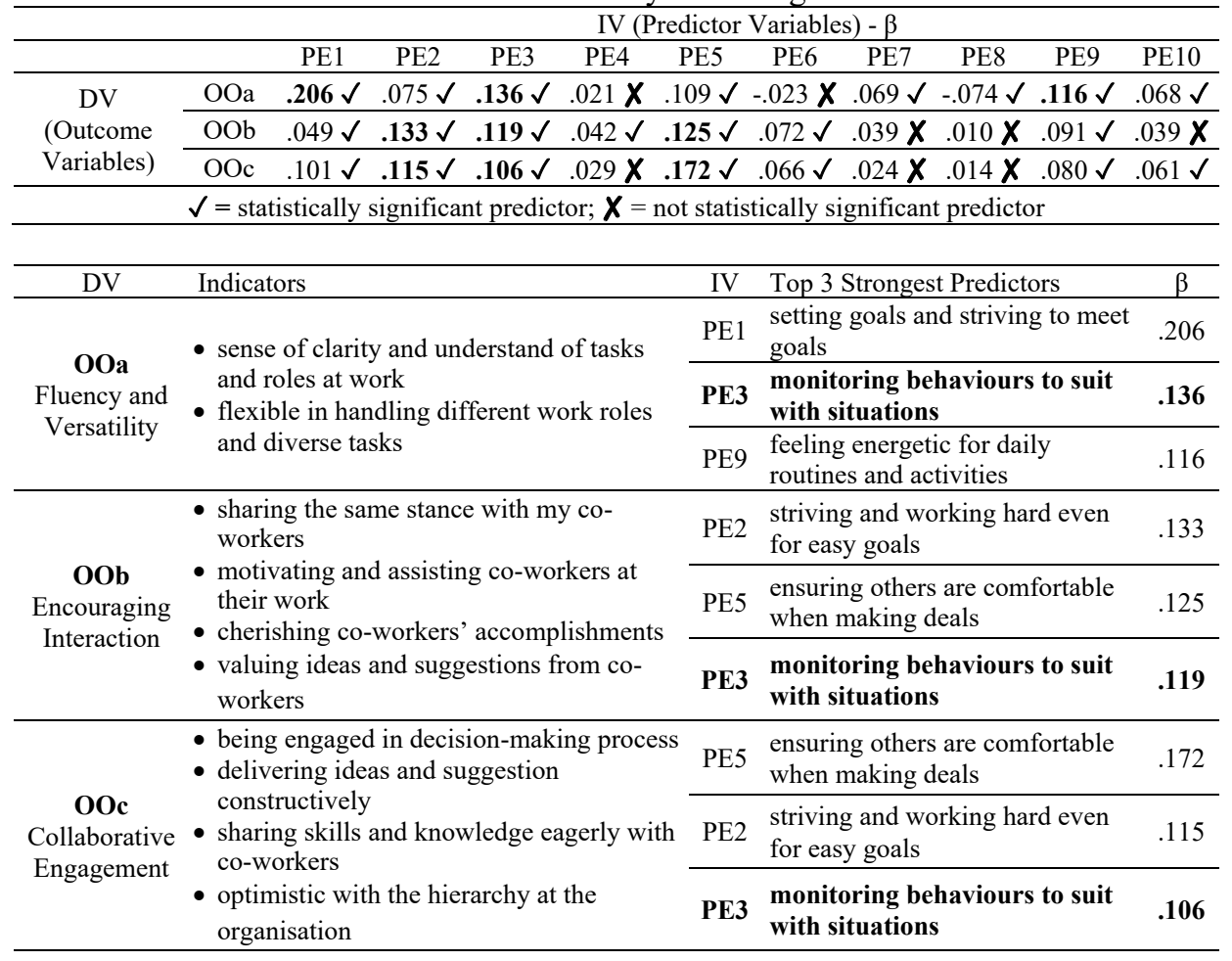

Findings show that majority of PE items significantly account for OOa, $\mathrm{OOb}$ and OOc. PE3, designating 'monitoring behaviours to suit with situations' was in the top three strongest predictors across OO components. The quality of coexisting and coinciding with social surrounding leads to OO. Handling emotions and behaviours consciously and rationally requires regular interactions to learn and acclimatise with the social atmosphere. Architectural planning of workspaces can influence human interactions. For instance, open spaces encourage more spontaneous and coincidental meetings and less pre-planned traditional meetings. Organisations can build networking cultures and encourage collaboration among co-workers leading to better performance and sustained organisational well-being. 
Aisyah Abu Bakar, Mariana Mohamed Osman \& Muhammad Faris Abdullah

Personal Empowerment as Determinants of Organisational Opportunity

\section{CONCLUSION}

$\mathrm{HIH}$ in SSWB propounds the idea that human expressions and behaviours need coexist harmoniously with concerns of others. This paper evidence that $\mathrm{OO}$ is predictable through PE. Statistical modelling on the constructs elaborated in this paper are the next steps in the future direction of the research.

\section{ACKNOWLEDGEMENT}

This research was supported by Post-Doctoral Fellow under Research Initatives Grant Scheme (RIGS-PDF), International Islamic University Malaysia (project title: RPDF19-005-0015)

\section{REFERENCES}

Aziz, Y. A., \& Ennew, C. (2013). Assessing the effects of empowerment and emotions on job satisfaction in hotel service environments. Pertanika Journal of Social Science and Humanities, 21(SPEC. ISSUE), 65-84.

Chin, N.-S., Khoo, S., \& Low, W.-Y. (2012). Self-determination and goal orientation in track and field. Journal of Human Kinetics, 33(1), 151-161.

Dancey, C., \& Reidy, J. (2004) Statistics without maths for psychology: Ssing SPSS for Windows. London: Prentice Hall.

Fatimah, O., Lukman, Z. M., Khairudin, R., Wan Shahrazad, W. S., \& Halim, F. W. (2011). Procrastination's relation with fear of failure, competence expectancy and intrinsic motivation. Pertanika Journal of Social Science and Humanities, 19(Special), 123-127.

Halim, F. W., Zainal, A., Omar, F., Hafidz, S. W. M., \& Othman, M. A. (2013). Exploring the mediating mechanisms in the personality-job performance relationship. Pertanika Journal of Social Science and Humanities, 21(December), 189-200.

Ho, J. A., Sambasivan, M., \& Liew, E. Y. (2013). The relationship between job insecurity, shock, and turnover intention, amongst survivors of organizational downsizing. Pertanika Journal of Social Science and Humanities, 21(Special), 101-114.

Ismail, F., Ahmad, N., Ismail, R., \& Janipha, N. A. I. (2012). The behavioural factors' characteristics of safety culture. Journal of Asian Behavioural Studies, 2, 67-75.

Kadir, N. B. A., Omar, F., Desa, A., \& Yusooff, F. (2013). Secure style, PWB-related gratitude and SWB-related engagement as predictors of affect balance among social science students in Malaysia: A pilot study. Pertanika Journal of Social Science and Humanities, 21, 85-98.

Kok, J. K. (2016). The relationships between procrastination and motivational aspects of self-regulation. Jurnal Psikologi Malaysia, 30(1), 30-39.

Liem, G. A. D., Martin, A. J., Porter, A. L., \& Colmar, S. (2012). Sociocultural antecedents of academic motivation and achievement: Role of values and achievement motives in achievement goals and academic performance. Asian Journal of Social Psychology, 15(1), 1-13.

Mokhtar, N., Husniyah, A. R., Sabri, M. F., \& Abu Talib, M. (2015). Financial well-being among public employees in Malaysia: A preliminary study. Asian Social Science, $11(18), 49-54$

Nesbit, P. L., Jepsen, D., Demirian, S., \& Ho, J. (2012). Extending self-leadership research to the East: Measurement equivalence of the Chinese and English versions of the MSLQ. Asian Journal of Social Psychology, 15(2), 101-111. 
Panatik, S. A., Zainal Badri, S. K., Rajab, A., Abdul Rahman, H., \& Mad Shaha, I. (2011). The impact of work family conflict on psychological well-being among school teachers in Malaysia. Social and Behavioral Sciences, 29(2010), 1500-1507.

Rashid, W. E. W., Nordin, M. S., Omar, A., \& Ismail, I. (2012). Work/family conflict: The link between self-esteem and satisfaction outcomes. Procedia - Social and Behavioral Sciences, 65(ICIBSoS), 564-569.

Salin, P. (2013). Islamic work ethics and organizational commitment: Evidence from employees of banking institutions in Malaysia. Social Sciences \& Humanities, 21(4), 1471-1489.

Sarina, M. N., \& Mohamad Adli, A. (2012). Quality work life among factory workers in Malaysia. Procedia - Social and Behavioral Sciences, 35(December 2011), 739745.

Sipon, S., Nasrah, S. K., Nazli, N. N. N. N., Abdullah, S., \& Othman, K. (2014). Stress and religious coping among flood victims. Procedia - Social and Behavioral Sciences, 140, 605-608.

Sulaiman, W. S. W., Kadir, N. B. A., Halim, F. W., Omar, F., Latiff, R. A., \& Sulaiman, W. S. W. (2013). Structural relations between personality traits, coping strategy, social support and well-being among adolescents. Pertanika Journal of Social Science and Humanities, 21(December), 121-134.

Zamani, Z. A., Khairudin, R., Sulaiman, W. S. W., Halim, F. W., \& Nasir, R. (2013). Relationship between achievement motivation and personality among pre and post-independence Malaysian Malays. Pertanika Journal of Social Science and Humanities, 21(December), 135-142

Received: $12^{\text {th }}$ January 2019. Accepted: $2^{\text {nd }}$ August 2019 